\title{
Интернет-механизмы вовлечения в экстремистские сообщества как угроза социализации современной молодежи
}

\author{
Юлия Р. Тагильцева', Ирина В. Воробьева', Ольга В. Кружкова ${ }^{1 *}$, \\ Дмитрий В. Руденкин ${ }^{2}$, Марина Р. Бабикова ${ }^{1,2}$, Дарья М. Никифорова' \\ 1 Уральский государственный педагогический университет, г. Екатеринбург, \\ Российская Федерация \\ 2 Уральский федеральный университет имени первого Президента России \\ Б. Н. Ельцина, г. Екатеринбург, Российская Федерация \\ *E-mail: galiat1@yandex.ru
}

\section{Аннотация}

Ввеление. В статье представлено обсужАение особенностей социализации современной молодежи и роли в этом процессе среды Интернета, имеющей широкие возможности по распространению различного по своим характеристикам контента. Особую угрозу в этом контексте имеют практика вовлечения через виртуальную среАу преАставителей молодежи в экстремистские сообщества и их радикализация. Новизна представленного исслеАования заключается в вылелении эфрфектов интернет-среды, обуславливающих специорику социализационных процессов молодежи и позволяющих описать конкретные косвенные и прямые угрозы Аля фризического и психического благополучия преАставителей молоАого поколения. Методы. Аля изучения потенциальных угроз со стороны виртуального пространства и выявления, используемых в нем, механизмов Аля вовлечения мололежи в экстремистские сообщества были проанализированы 2500 еАиниц креолизованных текстов, созАанных националистическими или религиозно-политическими экстремистскими группировками. Креолизованные тексты взяты с сайтов, солержащих материал экстремистского характера, а также в соответствующих группах во ВКонтакте.

Результаты. Были систематизированы наиболее типичные угрозы со стороны виртуального пространства Аля нормативной социализации трех возрастных категорий: млаАших школьников, поАростков и юношей. ПоАробно описаны механизмы вовлечения молодежи в экстремистские сообщества с применением разнообразных манипулятивных приемов. В частности, описываются приемы с применением смысловых искажений текстовой информации, визуальных образов и креолизованных текстов.

ОбсужАение результатов. Аелается вывоА, что описанные механизмы и приемы их реализации не являются единственными и неизменными, совершенствование 
Интернет-среды ведет за собой развитие техник воздействия на молодого человека. В то же время Аля нейтрализации указанных угроз целесообразно, помимо аАминистративных методов контроля интернет-контента, фрормировать резистентность молодежи к интернет-возАействию со стороны экстремистских сообществ.

\section{КАючевые слова}

Интернет, социализация, молодежь, экстремизм, экстремистские сообщества, механизмы вовлечения, интернет-угрозы, виртуальность, креолизованные тексты, эфроректы социализации

\section{Основные положения}

- социализация современной мололежи развертывается в иных условиях, в которых к^ючевую роль играет информационная составляющая, максимально широко представленная в среле Интернет;

- ^егкая Аоступность агрессивного, раликального, националистического контента в Интернете способствует возникновению особых рисков социализации мололежи, ведущих за собой не только освоение паттернов Аевиантного поведения, но и активное вовлечение представителей молоАежи в экстремистские сообщества;

- социализация молодежи, активно включенной в интернет-среду, протекает в том числе в поА влиянием «эфффекта Арейфра целей», мифологичности и «эфрфректа азарта»; эти эфффекты позволяют описать прямые и косвенные угрозы Аля ффизического и психического благополучия молодых пользователей Интернета;

- в контексте указанных эфрфектов описаны механизмы вовлечения мололежи в экстремистские сообщества, систематизированы используемые в них приемы с использованием текстовой и визуальной инорормации.

\section{Для цитирования}

Тагильцева Ю. Р., Воробьева И. В., Кружкова О. В., Руденкин Д. В., Бабикова М. Р., Никифорова Д. М. Интернет-механизмы вовлечения в экстремистские сообщества как угроза социализации современной молодежи // Российский психологический журнал. 2019. T. 16, № 1. C. 189-218. DOI: 10.21702/rpj.2019.1.9

Материалы статьи получены 16.05.2018 


\title{
Internet Mechanisms of Involvement in Extremist Communities as a Threat to Socialization of Contemporary Youth
}

\author{
Yulia R. Tagiltseva', Irina V. Vorobyeva', Olga V. Kruzhkova ${ }^{1}$, Dmitriy V. Rudenkin ${ }^{2}$, \\ Marina R. Babikova ${ }^{1,2}$, Darya M. Nikiforova ${ }^{1}$ \\ 1 Ural State Pedagogical University, Ekaterinburg, Russian Federation \\ ${ }^{2}$ Ural Federal University named after the first President of Russia B. N. Yeltsin, Ekaterinburg, \\ Russian Federation \\ *Corresponding author. E-mail: galiat1@yandex.ru
}

\begin{abstract}
Introduction. This study investigates how the Internet environment, which provides ample opportunities for content distribution, influences the socialization of contemporary youth. Involving young people in extremist communities and their radicalization through a virtual environment represent a particular threat in this context. This study analyses the effects of the Internet environment that determine the specific character of socialization processes in young people and describe specific indirect and direct threats to the physical and mental well-being of the younger generation.

Methods. To examine potential threats from the virtual space and to identify the mechanisms of young people's involvement in extremist communities, the authors analyzed 2.500 creolized text units created by nationalist or religious-political extremist groups. The creolized texts were extracted from the websites containing extremist materials and from the relevant groups in Vkontakte.

Results. The authors (a) systematized the most typical threats from the virtual space for the normative socialization of junior schoolchildren, adolescents, and young adults. The mechanisms of young people's involvement in extremist communities using various manipulative techniques are described in detail. In particular, the authors analyze the techniques of meaning distortions of text information, visual images, and creolized texts. Discussion. The described mechanisms and techniques of their implementation are not the only ones. The improvement of the Internet environment leads to the development of techniques of influence on young people. The authors suggest that besides the administrative methods of controlling Internet content, it is necessary to form young people's resistance to the influence of the Internet extremist communities.
\end{abstract}

\section{Keywords}

Internet, socialization, youth, extremism, extremist communities, mechanisms of involvement, Internet threats, virtuality, creolized texts, effects of socialization 


\section{Highlights}

- The socialization of contemporary young people is determined by the information component which is most widely presented in the Internet environment.

- The easy availability of aggressive, radical, and nationalist content on the Internet contributes to special risks of young people's socialization that entail the development of patterns of deviant behavior and young people's involvement in extremist communities. - The socialization of young people is influenced by 'drifting goals', mythology, and 'gamble effect'; these effects can describe direct and indirect threats to young Internet users' physical and mental well-being.

- In the context of these effects, the authors describe the mechanisms of young people's involvement in extremist communities and systematize the techniques of using text and visual information.

\section{For citation}

Tagiltseva Yu. R., Vorobyeva I. V., Kruzhkova O. V., Rudenkin D. V., Babikova M. R., Nikiforova D. M. Internet Mechanisms of Involvement in Extremist Communities as a Threat to Socialization of Contemporary Youth. Rossiiskii psikhologicheskii zhurnal - Russian Psychological Journal, 2019, V. 16, no. 1, pp. 189-218 (in Russian). DOI: 10.21702/rpj.2019.1.9

Original manuscript received 16.05.2018

\section{Введение}

Многие исследователи отмечают, что в настоящее время информационное воздействие на психику человека и общественное сознание растет колоссальными темпами. Используемые современные информационные технологии позволяют неограниченно контролировать и управлять информационным воздействием на общество [1]. В настоящее время Интернет является одним из самых используемых источников информации среди молодежи, поэтому он естественным образом оказывает влияние на процессы усвоения социальных норм молодым поколением. В то же время интернет-среда остается достаточно открытой для различного контента, в том числе носящего потенциальную угрозу радикализации пользователей Сети, вовлечения их в экстремистские сообщества [2, 3], что создает дополнительные риски социализации молодого поколения $[4,5]$.

Развитие глобальных компьютерных сетей и внедрение новых цифровых технологий приводят к зарождению так называемой «виртуальной реальности» (Джерон Ланье, 1989 г.), которая означает, «что реальное замещается искусственным миром из компьютера: человек может погрузиться в эту новую реальность так, как если бы она была настоящей» [6, с. 207]. В соответствии с этим в Интернете рождается новый вид социализации, который 
не сводится ни к первичной, ни к вторичной, т. к. осуществляется внутри виртуального пространства, а его результаты сказываются на конкретном человеке. Этот новый вид социализации может иметь двоякий результат: обеспечивать развитие как позитивной жизненной ориентации (привитой в результате первичной и вторичной социализации в реальном социуме), так и негативной (вести к десоциализации в реальном социуме) [7]. Интернет формирует особую коммуникативную среду, закономерности функционирования которой отличаются от тех, которые прослеживаются в любых иных формах коммуникации.

Молодежь заведомо более чутка к воздействию этой коммуникативной среды. С одной стороны, здесь сказывается прогрессирующая нелинейность процесса социализации молодежи в современном обществе. Уже само появление Интернета привело к изменению позиций молодежи в обществе. В трудах таких авторов, как Т. Барбер [8], Г. Одгард [9], В. А. Луков [10] социализация молодежи XXI в. описывается как нелинейный, лишенный предсказуемости процесс, исход которого во многом зависит от комбинации чисто ситуативных факторов. В работах других авторов (М. Бейзерман и Д. Магнуссон [11], С. А. Моримото и Л. А. Фридланд [12]) отражена идея об относительной автономности жизненного мира молодежи: в силу того, что молодежь успешнее осваивает новые социальные практики и технические новшества, ее жизненный мир может строиться на принципах, не зависящих от влияния более возрастных людей. Особые изменения в формируемых социальных паттернах молодежи произошли в последние полтора десятилетия, что частично обусловлено значительными преобразованиями, произошедшими в природе и функционировании Интернета за последнее время: появление Web 2.0 с акцентом на социальные сети, контент, созданный пользователями, и цифровое видео [13]. И очевидно, что и глубинная подоплека воздействия коммуникации в Интернете на молодежь, и факторы, которые влияют на это воздействие, требуют полноценного научного анализа.

Проблему только подчеркивает потенциальная двойственность воздействия коммуникации в Интернете на настроения молодежи. На современном этапе виртуализации жизни общества особую роль в формировании понимания реальности играет информация, в том числе распространяющаяся через сеть Интернет. Как отмечает Н. Винер, именно информация становится обозначением содержания, которое мы получаем из окружающего нас внешнего мира в процессе приспособления к нему [14]. В результате именно информация, с одной стороны, становится инструментом преобразования социальной реальности, а с другой - способствует порождению новых технологий, которые и формируют информационное пространство. Всё это способствует активизации информационного общества, но, в то же время, может порождать 
развитие деструктивной составляющей информации, направленной на повышение толерантности к опасным для общества практикам поведения. Иными словами, потенциально Интернет может служить источником патологий в социализации молодежи и приводить ее представителей к таким настроениям и поведенческим установкам, которые приведут к усилению дисфункциональных общественных процессов.

Здесь необходимо отметить, что Интернет представляет собой очень сложное коммуникативное пространство, и в нем присутствует много контента, направленного на провокацию пользователей на различные, в том числе и деструктивные для общества, действия. Не раз отмечалось, что посредством модульных вспышек информации [15] - команд, теорий, отрывков новостей, усеченных и заряженных определенными эмоциями, выходящих за границы ментальных ячеек, - средства массовой коммуникации формируют в сознании образы, посредством которых познается и воспринимается тот или иной объект. Именно этот собирательный образ выступает тем «спусковым механизмом», который вызывает к жизни определенные мысли, сопутствующие образы и реакции. В результате информация, несущая в себе определенный «заряд», воздействует, стимулирует эмоциональную сферу человека, вызывает ассоциативные связи, провоцирующие определенные состояния и соответствующие реакции. Всё это и делает ее инструментом манипулирования сознанием, направленного на формирование определенного общественного мнения и поведения, что позволяет заинтересованным кругам использовать ее для достижения своих целей. Поэтому в ход идут: дезинформирование, проявляемое в искажении и противоречивости информации, неточности подаваемых фактов, а также источников информации; информационная блокада, создаваемая за счет недопуска определенной части информации в открытую информационную среду, и т. д. Все эти приемы психологического воздействия в полной мере находят свое отражение в информационном пространстве Интернета.

Наличие в Интернете такого контента - источник рисков для социализации молодежи. Многие исследователи рассматривают Интернет как источник и среду социализации личности на протяжении всей жизни, выделяя при этом специфические особенности социализации в Интернете. Так, Т. В. Ефимова [16] отмечает опосредованный характер влияния агентов на социализацию; социализация в интернет-пространстве носит, в основном, стихийный характер; интернет-коммуникации ограничивают традиционные формы социализации (общение, игра, обучение и т. д.); личность в интернет-пространстве начинает усваивать нормы, цели, ценности, правила, принятые не конкретным обществом, в котором она живет, а тем сетевым сообществом, где доминируют нормы и ценности, не имеющие прочных историко-культурных корней. 
Эффекты от такой специфической социализации в Интернете бывают различными. В рамках российских и зарубежных исследований были выделены определенные психологические особенности пользователей виртуального пространства, которые формируются и развиваются при взаимодействии с Интернетом. Так, А. В. Минаков обозначил три специфических комплекса реакций, которые обозначил как «эффект дрейфа целей», «мифологичность» и «эффект азарта» [17]. Эфффект дрейфа челей проявляется в том случае, если при поиске информации первоначальная цель подменяется иными целевыми ориентирами. В результате психологическая направленность и интерес человека «дрейфуют» в плане переключения между многочисленными объектами виртуального пространства. Мифологичность Интернета реализуется через присвоение человеку в виртуальном пространстве возможностей, которых у него нет и не может быть в реальной жизни. Эффеект азарта проявляется в чрезмерной активизации поисковой активности индивида в пространстве Интернета в ущерб аналитической деятельности и критичной оценке поступающей информации. Однако Интернет не только формирует определенные поведенческие паттерны или смысловые установки, он навязывает систему ценностей и жизненных ориентиров [18], а молодежь, не перерабатывая поступающую информацию и становясь объектом воздействия, формирует на основе этой системы ценностей свои намерения и реализует их в поведении [19].

Понимание эффектов воздействия Интернета на настроения и поведенческие установки молодежи важно для понимания возникающих рисков и осуществления их профилактики. Дальнейшее распространение Интернета в обществе и совершенствование его инструментария - по всей видимости, неизбежная тенденция. На сегодняшний день Интернет становится самым эффективным средством массовой коммуникации, поскольку, как отмечают М. Моррис и К. Оган, для него характерны четыре типа коммуникации: асинхронная коммуникация «один на один»; асинхронная коммуникация «многих с многими»; синхронная коммуникация «один на один», «один с несколько», «один с несколькими», выстраиваемая во круг одной темы; асинхронная коммуникация «многие и один», «один на один», «один и многие», где пользователи находятся в поиске информации, переходя с сайта на сайт [20]. Всё это приводит к формированию специфических свойств виртуальной реальности [21]:

1. Погружение (пользователь «входит» в виртуальную реальность, созданную компьютером).

2. Многомерность (виртуальное пространство обладает качествами двухи трехмерного измерения).

3. Мультисенсорика (восприятие виртуальной реальности происходит за счет нескольких характеристик перцептивной системы организма человека - зрительной, слуховой, кожной и др.). 
4. Реальное время (симультанность и взаимозависимость актов пользователя от трансформации среды).

5. Адекватность (в виртуальной реальности индивидом усваиваются те образы, которые соответствуют реальным и оправдывают его ожидания).

6. Интеракция (пользователь может моделировать виртуальное пространство).

7. Проницаемость (перемещение индивида в виртуальном пространстве имеет разноуровневую направленность движения).

8. Эффект реальности (виртуальное пространство представляет собой симулякр реального мира, попадая в который, пользователь испытывает его материальность).

9. Эффект многих пользователей (виртуальная реальность создает такое коммуникативное пространство, в котором наблюдается повышенная плотность взаимодействий).

Всё это не только способствует популяризации Интернета как средства распространения информации и общения, но и делает его весьма привлекательным инструментом воздействия на массовое сознание, поскольку в нем можно создавать более или менее устойчивые виртуальные сообщества, объединяемые общими интересами, потребностями в общении. Это и дает возможность заинтересованным кругам использовать его для достижения своих целей.

Неизбежное интенсивное распространение Интернета в обществе и наличие в нем явных социализационных рисков формируют запрос на изучение различных особенностей его воздействия на настроения молодежи. Всё большая обеспокоенность проявляется со стороны ученых, государственных органов и общественности относительно того, что легкая доступность насильственного экстремистского контента в Интернете может иметь сильные радикализирующие последствия [22]. Безусловно, сам по себе Интернет не действует как радикализирующий агент, однако он может служить посредником и катализатором для реализации целей экстремистских сообществ [23], в том числе через открытый доступ к коммуникации определенных, готовых к принятию такого воздействия категорий молодежи (как правило, для молодых людей содержание идеологии не является первым стимулом для вступления в экстремистские сообщества, но готовность к этому, прежде всего, возникает у них через общее недовольство обществом, поиск путей борьбы с этим недовольством) [24].

В рамках проблемы распространения идей экстремистской направленности исследователями особое место отводится именно информационному фактору [3] как своеобразному инструменту формирования информационной агрессии, под которой понимается «манипулирование информацией, 


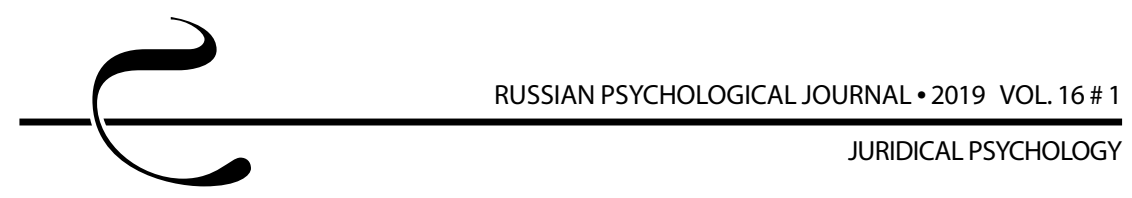

провоцирующее нарушение целостности общества, его стабильности, в том числе и эмоционального состояния, подрыв целей, взглядов и мировоззрения населения, а также разжигания конфликтов (межличностных, этнических, международных)» [25, с. 65]. И здесь важно понять, какие факторы и задействованные механизмы заставляют молодых людей - пользователей Интернета участвовать в рискованных действиях в интернет-среде, делают их уязвимыми для воздействия экстремистских и радикальных сообществ через социальные сети или иные интернет-ресурсы с учетом социализационных тенденций современной молодежи.

\section{Методы}

Для изучения потенциальных угроз со стороны виртуального пространства и выявления используемых в нем механизмов для вовлечения молодежи в экстремистские сообщества были проанализированы 2500 единиц креолизованных текстов, созданных националистическими или религиозно-политическими экстремистскими группировками. Креолизованные тексты взяты с сайтов, содержащих материал экстремистского характера национальной или религиозной направленности, в том числе в подобных группах во ВКонтакте.

Основной метод нашего исследования - дискурсивный анализ - является одним из основных методов исследования материалов экстремистской направленности. В данном случае важность обусловлена выявлением социального контекста, стоящего за устной или письменной речью. Дискурсивный анализ осуществлялся нами с точки зрения социолингвистического подхода, включающего в себя следующие параметры: характеристику типовых участников; описание хронотопа; выявление целей; определение ценностей; описание основных стратегий; описание ключевых жанров, прецедентных текстов и дискурсивных формул [26].

Когнитивное исследование осуществлялось нами с опорой на теорию Т. А. ван Дейка $[27,28]$ и включало в себя два уровня исследования: текстуальный анализ и контекстуальный анализ. Текстуальный анализ предполагал структурный анализ собранного материала на всех его уровнях: фонетический, графический, морфологический, синтаксический, семантика и лексика, уровень макроструктур и риторический аспект.

Контекстуальный аспект анализа предполагал рассмотрение материалов с позиций контекста: время, место, событие/действие, сфера деятельности, участники, роли участников, социальные отношения, когнитивные характеристики участников. Контекстуальный аспект когнитивного исследования во многом перекликается с дискурсивным анализом, однако нами данный аспект применялся к конкретным примерам (экстремистским материалам): этот 
момент важен при анализе разного рода материалов, т. К., к примеру, в рамках национального экстремизма контекст играет огромную роль - нацистская символика может быть использована с целью создания художественного образа, и в таком примере приписывание экстремистских мотивов будет противоречить действительности (хотя и носит дискуссионный характер), а в некоторых других примерах, в рамках определенного контекста экстремистскую направленность могут приобретать, казалось бы, безобидные образы, например, образ славянина.

Моделирование в лингвистике дает возможность выявить и изучить структуру разнообразных языковых явлений, что в свою очередь способствует уточнению понятий, а также их связей при изучении языка. Специфика данного метода, как отмечает А. Ф. Лосев, заключается в том, что «языковая модель обязательно предполагает наличие таких общих моментов, как: принцип структуры объекта; сама структура объекта; структура, данная в деталях; перенесение данной структуры на новый объект и соответствующая организация этого объекта» [29, с. 28].

При обобщении, систематизации и интерпретации результатов наблюдений применяется описательный метод.

\section{Результаты}

Анализ интернет-контента позволил систематизировать угрозы согласно описанным выше эффектам Глобальной сети. Для понимания возможной глубины воздействия на физическое и психическое благополучие пользователей они были разделены на прямые (предполагают реальные риски жизни и здоровью) и косвенные (апеллируют к изменению моделей поведения человека и способствуют формированию аддикции или потенциально небезопасного поведения).

Таким образом, риски вовлечения в экстремистские сообщества с помощью Интернета так или иначе присутствуют, начиная с младшего школьного возраста, т. е. того периода развития личности, когда ребенок начинает проявлять самостоятельную активность в Глобальной сети. Опишем механизмы воздействия на выделенные нами эффекты интернет-среды экстремистского контента. 
Таблица 1. Соотношение угроз и эфоректов интернет-среды

Table 1. Interrelationships between threats and effects of the Internet environment

\begin{tabular}{|c|c|c|c|}
\hline \multirow{2}{*}{$\begin{array}{c}\text { Угрозы со } \\
\text { стороны } \\
\text { Интернета }\end{array}$} & \multicolumn{3}{|c|}{ Эффекты интернет-среды } \\
\hline & $\begin{array}{c}\text { Эффект Арейфра } \\
\text { целей }\end{array}$ & Мифологичность & Эффрект азарта \\
\hline \multicolumn{4}{|c|}{ М^аАший школьный возраст } \\
\hline $\begin{array}{l}\text { Прямые } \\
\text { угрозы }\end{array}$ & $\begin{array}{l}\text { Опасность стать } \\
\text { жертвой педо- } \\
\text { фрила, грабителя } \\
\text { и др., навязывание } \\
\text { непристойной } \\
\text { инфоормации }\end{array}$ & $\begin{array}{l}\text { Призывы к нео- } \\
\text { сознанному су- } \\
\text { ициду, убийству, } \\
\text { краже и т. п. } \\
\text { («Стань фреей } \\
\text { огня») }\end{array}$ & $\begin{array}{l}\text { Перенос игровых } \\
\text { ситуаций, предпо- } \\
\text { ^агающих риск, } \\
\text { в реальность; про- } \\
\text { вокация агрессив- } \\
\text { ного поведения }\end{array}$ \\
\hline $\begin{array}{l}\text { Косвенные } \\
\text { угрозы }\end{array}$ & $\begin{array}{l}\text { Замена образо- } \\
\text { вательной актив- } \\
\text { ности геАонисти- } \\
\text { ческой и игровой } \\
\text { Аеятельностью, как } \\
\text { слеАствие сни- } \\
\text { жение школьной } \\
\text { успеваемости. } \\
\text { Формирование } \\
\text { паттернов } \\
\text { спонтанной по- } \\
\text { купательской } \\
\text { активности. } \\
\text { Навязывание } \\
\text { устойчивого ви- } \\
\text { зуального ряда } \\
\text { экстремистских } \\
\text { символов посреА- } \\
\text { ством их вкґюче- } \\
\text { ния в привычные } \\
\text { позитивно оцени- } \\
\text { ваемые образы }\end{array}$ & $\begin{array}{l}\text { Ухол в вирту- } \\
\text { альную реаль- } \\
\text { ность через } \\
\text { онлайн-игры } \\
\text { Искажение об- } \\
\text { раза реальности } \\
\text { и образа я (на- } \\
\text { деление себя } \\
\text { или мира несу- } \\
\text { ществующими } \\
\text { возможностями) }\end{array}$ & $\begin{array}{l}\text { Формирование } \\
\text { стремления к по- } \\
\text { иску социального } \\
\text { одобрения посред- } \\
\text { ством сбора «лай- } \\
\text { ков» через совер- } \\
\text { шения эпатажных } \\
\text { и рискованных Аей- } \\
\text { ствий «на камеру» }\end{array}$ \\
\hline
\end{tabular}




\begin{tabular}{|c|c|c|c|}
\hline \multicolumn{4}{|c|}{ ПоАростковый возраст } \\
\hline $\begin{array}{l}\text { Прямые } \\
\text { угрозы }\end{array}$ & $\begin{array}{l}\text { Вовлечение в экс- } \\
\text { тремистские } \\
\text { сообщества, по- } \\
\text { пуляризирующие } \\
\text { практики Аевиант- } \\
\text { ного, в том числе } \\
\text { аутоагрессивного, } \\
\text { поведения (кибер- } \\
\text { булминг, киберсу- } \\
\text { ициА, согласован- } \\
\text { ный суицил) }\end{array}$ & $\begin{array}{l}\text { Вовлечение } \\
\text { в порнографию. } \\
\text { Формирование } \\
\text { ^ожных прел- } \\
\text { ставлений } \\
\text { о себе и своих } \\
\text { возможностях. } \\
\text { Проявение } \\
\text { жестокого по- } \\
\text { ведения, агрес- } \\
\text { сии (при пере- } \\
\text { несении образа } \\
\text { в реальный мир) }\end{array}$ & 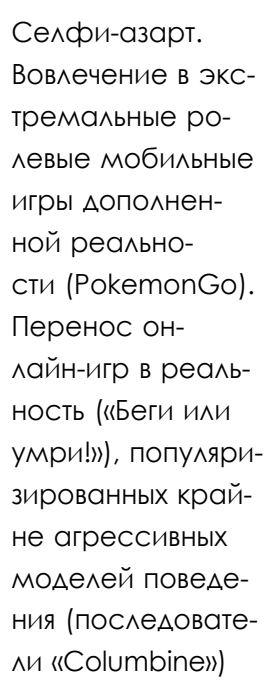 \\
\hline $\begin{array}{l}\text { Косвенные } \\
\text { угрозы }\end{array}$ & $\begin{array}{l}\text { Вовлечение } \\
\text { в субкультуры. } \\
\text { Разглашение пер- } \\
\text { сональной ин- } \\
\text { орормации (в том } \\
\text { числе геолока- } \\
\text { ции). Некритичное } \\
\text { принятие и ис- } \\
\text { пользование гото- } \\
\text { вых моделей по- } \\
\text { ведения из Сети. } \\
\text { Формирование } \\
\text { навязанных } \\
\text { потребностей }\end{array}$ & $\begin{array}{l}\text { Замена реаль- } \\
\text { ной социальной } \\
\text { активности ак- } \\
\text { тивностью в вир- } \\
\text { туальной среАе. } \\
\text { Провокация раАи- } \\
\text { кальных решений } \\
\text { о своей жизни, } \\
\text { ухоАов из Аома, } \\
\text { эпатажных по- } \\
\text { ступков и т. п. } \\
\text { Развитие и поА- } \\
\text { Аержание орто- } \\
\text { Аоксального взгля- } \\
\text { Аа на мир [30] }\end{array}$ & $\begin{array}{l}\text { Провокация алре- } \\
\text { налиномании, } \\
\text { эмоционального } \\
\text { перевозбужАения. } \\
\text { И^^юзия активной } \\
\text { жизнедеятельности, } \\
\text { коммуникаций }\end{array}$ \\
\hline
\end{tabular}




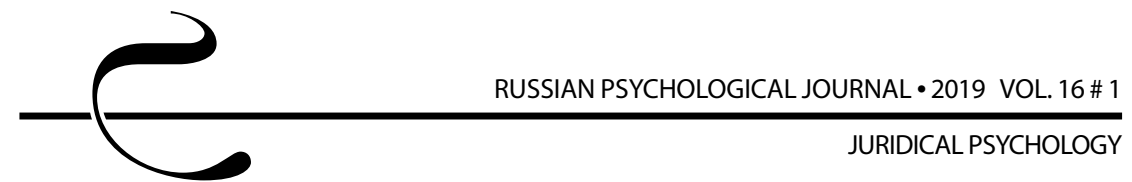

\begin{tabular}{|c|c|c|c|}
\hline \multicolumn{4}{|c|}{ Юношеский возраст } \\
\hline $\begin{array}{l}\text { Прямые } \\
\text { угрозы }\end{array}$ & $\begin{array}{l}\text { Вовлечение в экс- } \\
\text { тремистские } \\
\text { группировки } \\
\text { и орормирование } \\
\text { экстремистского } \\
\text { поведения }\end{array}$ & $\begin{array}{l}\text { Изменение } \\
\text { мировоззрения } \\
\text { человека (илео- } \\
\text { ^огизация ми- } \\
\text { ровоззрения как } \\
\text { инструмента } \\
\text { внешней манипу- } \\
\text { ^яции со сторо- } \\
\text { ны религиозных } \\
\text { и экстремистских } \\
\text { сообществ) }\end{array}$ & $\begin{array}{l}\text { Игра «на слабо», } \\
\text { вовлечение в азарт- } \\
\text { ные игры с риском } \\
\text { Аля жизни. } \\
\text { Стимуляция соци- } \\
\text { ально-опасного } \\
\text { поведения через ин- } \\
\text { тернет-инструкции } \\
\text { по самостоятельно- } \\
\text { му приготовлению } \\
\text { наркотиков, взрыв- } \\
\text { чатки и мр. }\end{array}$ \\
\hline $\begin{array}{l}\text { Косвенные } \\
\text { угрозы }\end{array}$ & $\begin{array}{l}\text { Смещение при- } \\
\text { оритетов и цен- } \\
\text { ностей с фризиче- } \\
\text { ской на виртуаль- } \\
\text { ную среду (интер- } \\
\text { нет-знакомства, } \\
\text { просмотр обзо- } \\
\text { ров о событии } \\
\text { во время участия } \\
\text { в самом собы- } \\
\text { тии, видеоблогинг } \\
\text { и пр.) }\end{array}$ & $\begin{array}{l}\text { И^^юзорный об- } \\
\text { раз себя, измене- } \\
\text { ния себя под этот } \\
\text { образ (п^астиче- } \\
\text { ские операции, } \\
\text { пирсинг, татуи- } \\
\text { ровки и пр.) }\end{array}$ & $\begin{array}{l}\text { Аисгармонизация } \\
\text { инАивиАуального } \\
\text { развития, трата Ае- } \\
\text { нег в сети, социаль- } \\
\text { ная ретардация (за- } \\
\text { Аержка в социаль- } \\
\text { ном развитии) }\end{array}$ \\
\hline
\end{tabular}

\section{Эффект дрейфа целей}

Данный эффект создается с целью популяризации экстремистского материала: «введение» в символику, запоминание ключевых символов, транслирующих экстремистские настроения с последующим воспроизведением. Кроме того, дрейф целей предполагает, с одной стороны, идентификацию символики, с другой стороны, ее дифференциацию. Авторы экстремистских 
текстов вводят в качестве центрального компонента безобидный, известный всем с детства образ - Леопольда, Винни-Пуха, Пятачка, Карлсона и Малыша, Хрюши и др., наделенный соответствующей экстремистской символикой, совершающий определенные действия и задающий адресату необходимую манипулятору модель восприятия окружающего мира и, как следствие, поведения, которые требуют распространения и популяризации. В данном случае наличие вербального компонента сводится к минимуму, что обусловлено спецификой восприятия информации детьми данной возрастной группы.

Выражение данного эффекта варьируется в зависимости от возрастной категории адресатов.

Так, в националистическом дискурсе встречается плакат, центральным изображением которого является образ всеми узнаваемого и известного большинству детей младшего школьного возраста - Зайца из мультфильма «Ну, погоди!». Заяц изображен в гиперболизированной форме (демонстрирующий бицепс) и сопровожден следующими атрибутами: черный прямоугольник на глазах, на белой футболке четко отражается изображение шапочного знака отряда СС - «Мертвая голова», располагавшегося обычно на фуражке, петлицах или кокардах представителей отряда, отвечавших за охрану концентрационных лагерей Третьего Рейха. Символ использован с целью привлечения внимания любопытных учеников, а также для введения в тему национального экстремизма.

Подобного плана изображение находим и на рисунке 1а. На картинке представлен герой современного мультфильма: «Дружба - это чудо» (англ. «Му Little Pony: Friendship is Magic») - «Сумеречная Искорка» с флагом нацистской Германии, актуализирующем в сознании знающей аудитории все ужасы фашистского режима; но по отношению к младшим школьникам данный символ введен с целью ознакомления с последующей заинтересованностью в нем.

Для старших возрастов, подросткового и юношеского, авторы экстремистских текстов прибегают к использованию креолизованных текстов разных типов: например, комиксов или фотоколлажей. На рисунке 16 представлен фотоколлаж, целью которого является оправдание и популяризация «родноверия» и осквернение христианской религии. Так, слева представлены фото христиан, исполняющих те или иные церковные обряды с подкрепляющей надписью: «Овцы дома Израилева». Данная фраза современным поколением может быть истолкована неверно, точнее буквально, что будет продиктовано знанием только переносного значения существительного «овца» и ограниченностью познаний в области христианской религии и текста Библии. В результате, в сознании адресата формируется отрицательный образ верующих данной конфессии, в отличие от «родноверия» (нового религиозного движения, провозглашающего своей целью возрождение славянских 


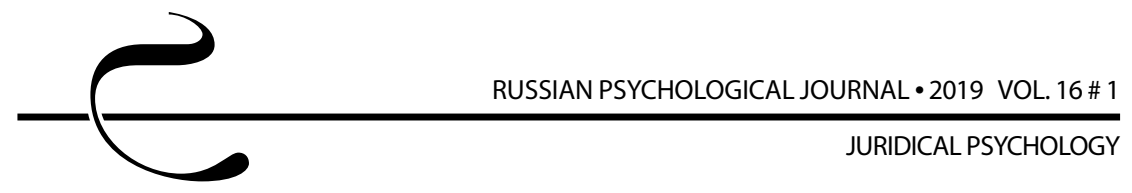

дохристианских обрядов и верований), фотоколлаж которого представлен справа и сопровожден вербальной пометой: «Дочери РОДных богов».

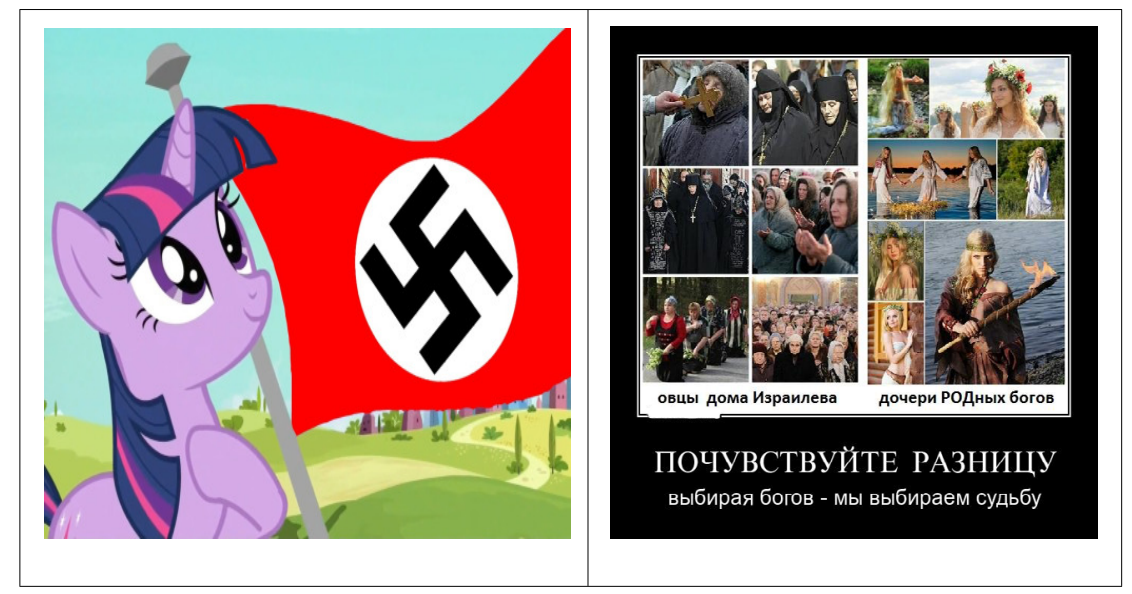

a)

б)

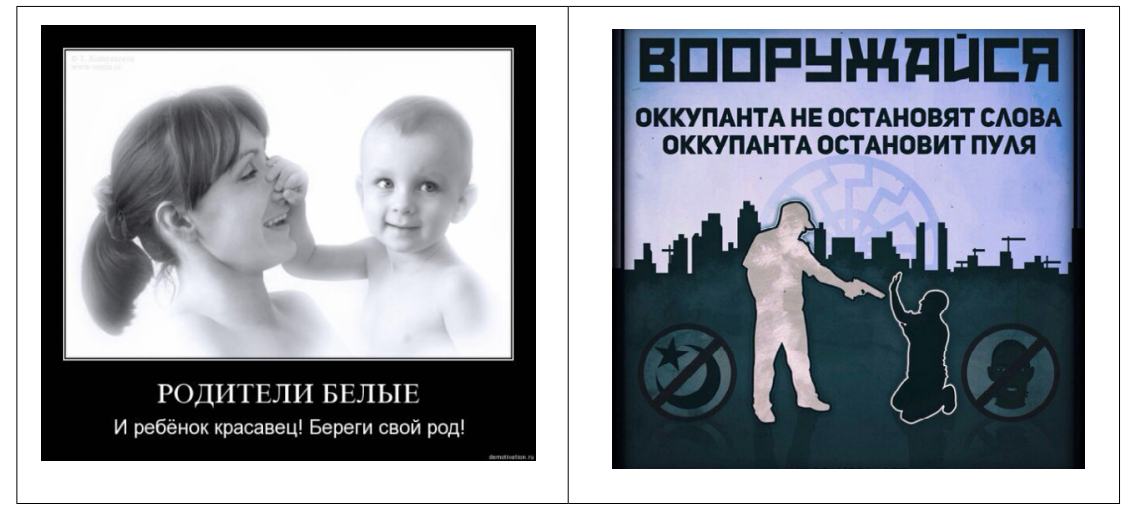

B)

г)

Рисунок 1. Креолизованные тексты экстремистской националистической направленности (взяты из Интернета)

Figure 1. Extremist nationalist creolized texts (from the Internet)

Перед подростком/юношей стоит цель: выбор «правильной» религии. Однако введение в креолизованный текст риторического вопроса «ПОЧУВСТВУЙТЕ РАЗНИЦУ. Выбирая богов - мы выбираем судьбу» 
побуждает к дрейфованию между двумя религиями, а представление христианства в дискредитирующем облике способно как раз и спровоцировать неокрепшую детскую психику к выбору деструктивной стороны.

Таким образом, экстремистские материалы, созданные на основе эффекта дрейфа целей, способны вовлекать подростков и юношей в экстремистские и иные субкультурные группировки, а также формировать основы экстремистского поведения.

\section{Эффект мифологичности}

В рамках данного вида эффекта происходит воздействие на две возрастные группы-подростковую и юношескую, поскольку они уже имеют более зрелое восприятие и мышление, а также у большинства из них уже сформирован значительный объем фоновых знаний. В данном случае создаются креолизованные тексты, усложненные дополнительными смыслами, что требует от адресатов владение определенными материальными и духовными ценностями, с более объемными вербальными компонентами: с разнообразной лексикой, работающей на реализацию различных стратегий и тактик, преследуемых авторами потенциально опасных материалов, распространяемых в сети Интернет, с символикой экстремистской направленности. Всё это приводит и к расширению круга тем, вовлекающих подростков и юношей в экстремистскую деятельность.

Такие креолизованные тексты направлены на создание фантомного, мифологичного социума как варианта желаемой реальности, в котором представлены только «свои», кажущиеся привлекательными, транслирующие безопасность и придающие адресату уверенность и значимость. Мир желаемой реальности - это общество только «своих» без «чужих» (в данном случае авторы статьи опираются на бинарную оппозицию «свой - чужой» как одну из ключевых противопоставлений в жизни и устройстве общества и актуальную для многих типов дискурса) [31, 32]. Но стоит отметить, что «чужие» в текстах экстремистской направленности нужны для того, чтобы сильнее осознать свою причастность к «своей» группе [33].

Так, например, на рисунке 1в представлено изображение, передающее националистические настроения авторов: девушка с ребенком славянской внешности (отметим, что образ славянского человека - один из самых распространенных образов в национальном экстремизме [34]) являются символом чистоты, преданности (в первую очередь, славянскому роду), истинной любви, очерчивая тем самым круг «своих». На это также указывает и вербальный компонент креолизованного текста: «РОДИТЕЛИ БЕЛЫЕ. И ребенок красавец! Береги свой род!».

Посредством эффекта мифологичности происходит формирование установок на возрождение и сохранение славянского рода, а призывы к обереганию 
своего рода воспринимаются уже своеобразным латентным призывом к противостоянию «чужим», которыми в национальном экстремизме обычно предстают лица неславянской внешности.

Специфика же религиозно-политического экстремизма заключается в популяризации, прежде всего, определенной религиозной системы ценностей и императивов, вбирающей в себя некоторые положения фундаментализма: возвращение превалирующей роли религиозным структурам в обществе, привилегированность религиозного направления, завуалированность политических идей под религиозные постулаты - всё это делает «секты» деструктивного характера весьма привлекательными для адептов [35].

Кроме того, эффект мифологичности позволяет манипуляторам создавать круг тем, наполненных своеобразным звучанием и оправдывающих террористическую или экстремистскую деятельность их группировки. Например, во многих исламских религиозных текстах экстремистской направленности встречаются темы «правильности религии (ислама)», «джихада (джихада меча) - священной войны с неверными», «исторической несправедливости по отношению к мусульманам» и «оправдания насильственных действий во имя Аллаха», «превосходства ислама над всеми другими религиями». Такие темы способствуют формированию в сознании аудитории определенного образа социума «своих», обладающего определенным набором религиозных и политических императивов, системой ценностей, образом жизни.

В качестве примеров встречаются такие плакаты, на которых представлены собирательные образы несущихся на арабских скакунах воинов ислама, атрибутами которых становятся мечи, щиты, покрытое куфией (мужской головной платок, служащий для защиты головы и лица от солнца, песка и холода) лицо. Практически каждый второй из них держит черный флаг с белой «шахадой», означающей «Никакого халифата без таухида и джихада». Данный флаг принадлежит «Аль-Каиде», которая представляет собой одну из самых крупных ультрарадикальных международных террористических организаций ваххабистского направления ислама (организации, запрещенные на территории Российской Федерации). На одном из изображений в правом верхнем углу дается символика другой террористической группировки - белая шахада на черном фоне и с горизонтальной саблей внизу - Кавказского эмирата (Имарат Кавказ) (организация, запрещенная на территории Российской Федерации), представляющего собой сепаратистско-террористическое радикально исламское подполье, деятельность которого заключалась в нападении на российских военнослужащих, сотрудников спецслужб, полицейских, а также убийств мирных граждан, проведении терактов, обстрелов, подрывов на территории Чечни.

Компонентом воздействия является изречение: «That is the right religion, so don't wrong yourselves, and Fight against the Mushrikun collectively, as they Fight 
against you collectively». - «Это правильная религия, поэтому не обманывайте себя и боритесь против мушриков коллективно также, как и они, объединившись, борются против нас» (взято из Интернета). Оно, во-первых, указывает на имплицитное превосходство одной религии над другой посредством существительного «мушрики» (язычники, признающие наряду с Богом наличие и других божеств или полубожеств), во-вторых, призывает к осуществлению действий - «боритесь против».

Подобные креолизованные тексты способствуют популяризации среди молодежи идей исламского фундаментализма.

Способы противостояния «чужим» наглядно демонстрируются благодаря эффекту азарта.

\section{Эффект азарта}

Поскольку круг «своих» четко очерчен эффектом мифологичности, то эффект азарта уже задает новоиспеченным адептам экстремистских группировок в объемных креолизованных текстах определенный алгоритм поведения, включающий в себя демонстрацию навыков, умений, а также методов и способов «взаимодействия» с «чужими» (обычно выражающийся в агрессивных действиях). Всё это приводит к сужению круга тем до криминальной, преступнической тематики и оправданию насильственных действий во имя справедливости.

Рассматриваемый психологический эффект имеет направленность только на две возрастные категории - подростков и юношей. Однако следует отметить, что в большей степени подвержены влиянию экстремистских материалов юноши, поскольку эту категорию в основном составляют студенты, которые способны уже активно транслировать националистические идеи, способны принимать активное участие в националистических митингах, акциях. Студенческая аудитория наиболее эмоциональна в силу юношеского максимализма и односложного черно-белого восприятия межнациональных и межрелигиозных отношений. Возрастные особенности студенчества, по мнению исследователей, характеризуются более высокими протестными настроениями, повышенной активностью и решительностью $[36,37]$.

Например, на рисунке 1г схематично представлена сцена расправы над «чужим», на что указывают цветовые различия между силуэтами мужчин: стоящий на коленях мужчина изображен в черном цвете - как символ выходца с Кавказа, белым представлен славянин. Кроме того, под знаки запрета помещены (при чтении слева направо): 1) символ исламской религии (полумесяц и пятиконечная звезда), 2) образ мужчины негроидной расы - символизирующие антагонистов национального экстремизма.

Эффект азарта, представленный визуальным рядом, сопровождается вербальным компонентом: «ВООРУЖАЙСЯ! Оккупанта не остановят слова, 
оккупанта остановит пуля». Призывная форма глагола «вооружайся» дает установку к действию молодому поколению, демонстрируя тем самым беспощадное и безапелляционное отношение к «врагу».

Если затрагивать тему религиозного / религиозно-политического экстремизма, можно отметить пример (плакат), в рамках которого изображены символы двух мировых конфессий - ислама (полумесяц со звездой) и христианства (православный крест), перечеркнутые красным крестом, что свидетельствует о недопустимости, невозможности сосуществования их вместе. Всё это сопровождается надписью - цитатой из Корана (в одном из переводов), взятой из суры 5 Аль-Маида «Трапеза» аята 51: «О те, которые уверовали! Не считайте иудеев и христиан своими друзьями, поскольку они друзья друг другу».

Выделенные компоненты экстремистских текстов, участвующих в формировании эффектов интернет-среды, дают возможность наглядно охарактеризовать не только механизм воздействия на психику индивиду, но и определить систему компонентов (визуальных образов и вербальной составляющей), посредством которых достаточно эффективно меняются картина мира индивида и модель его поведения.

\section{Обсуждение результатов}

Описание возможных механизмов вовлечения молодежи в сообщества экстремистского толка позволяет констатировать тот факт, что на сегодняшний день в сети Интернет распространено огромное количество текстов, картинок, видеоматериалов, символов и прочей атрибутики экстремизма, характеризующееся большим пропагандистским потенциалом. В совокупности с использованием самоорганизующихся агрегатов (специальных групп, сформированных посредством связи со страницей Facebook или ее аналогом), которые популяризируются в пространстве Интернета до начала кампаний экстремистских сообществ в реальном мире [38], описанные механизмы и приемы способствуют росту угроз социализации молодых поколений.

Утверждать, что каждый из возможных элементов способен привлечь одинаковое внимание, неправомерно. Проведенные исследования [39, 40, 41, 42, 43, 44, 45 и др.] дают основания выделять наиболее действенные компоненты, способствующие не только привлечению, но и формированию определенного «эмоционального заряда» информации:

1. Символика (начистская, пронацистская и символика иных организаций, которые признаны экстремистскими).

Все чаще на стенах домов мы видим изображения свастики и другой нацистской атрибутики и символики, где сообщением адресант призывает к активным действиям националистического толка. Особенно активно подобная символика пропагандируется в Интернете. Это зачастую становится 
орудием вербовки молодежи в ряды современных фанатиков. Несмотря на то, что в Российской Федерации «пропаганда и публичное демонстрирование нацистской атрибутики или символики, либо атрибутики или символики, сходных с нацистской атрибутикой или символикой до степени смешения» (ФЗ № 114 от 25 июля 2002 г.) признаны экстремистской деятельностью, современные экстремисты проявляют удивительную изворотливость, стремясь представить свою деятельность как не противоречащую законодательству.

2. Креолизованный текст (вербальный текст и изображение, субъекты и объекты изображения), понимаемый как «текст, обладающий сложной формой, то есть основанный на сочетании единиц двух и более различных семиотических систем, которые вступают в отношения взаимосвязи, взаимодополнения, взаимовлияния, что обуславливает комплексное воздействие на адресата» [46, с. 21]. Популярность указанного вида репрезентации экстремистских идей объяснима высоким прагматическим потенциалом. Эпоха клипового мышление и активное пользование Глобальной сетью диктуют новые способы подачи информации: зрительный образ, находящийся в центре креолизованного текста, гораздо быстрее найдет отклик в сознании адресата, а меткое вербальное дополнение закрепит и усилит увиденный образ. К наиболее популярным видам креолизованного текста в экстремистском дискурсе относятся: плакат, листовка, демотиватор, граффити, карикатуры, видеопослания и т.д.

3. Вербальный текст - классический вариант изложения идеологии той или иной экстремисткой группировки. Анализ текстов экстремистской направленности позволил выделить следующие наиболее частотные группы языковых приемов воздействия на сознание адресата:

1) элементы агрессии (милитарная лексика: существительные, обозначающие военные действия, прилагательные, означающие признак действия, а также глаголы и их глагольные формы: зарезать, убить, выгнать, nоджечь, восстать, и другие; метафорические образы);

2) организация «фантомного мира» (некой социальной/религиозной группы, к которой принадлежит говорящий) посредством «языковой демагогии», представляющей собой разделение на «своих» и «чужих»;

3) речевые стратегии уговаривания, запугивая, дискредитации;

4) приемы языковой манипуляции: использование пречедентных феноменов, особенности синтаксических конструкций предложения: риторические вопросы, открытый текст, восклицательные конструкции и т..

4) темы. Классификация экстремистики направленного материала позволяет выделить наиболее актуальные темы, которые затрагивают экстремисты, манипулируя сознанием адресатов:

- «священная» война за свои «права»; 


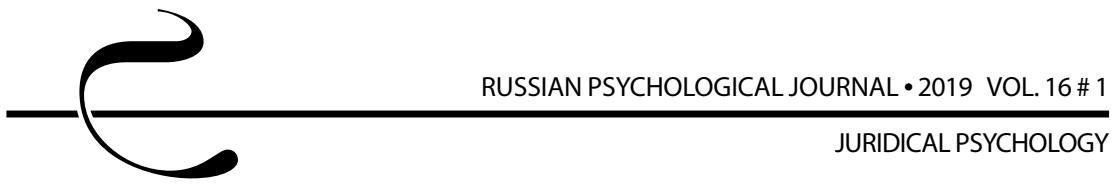

- несправедливость (чаще всего историческая) по отношению к какому-либо этносу, нации и т. п.;

- оправдание террористической деятельности во имя сохранения религии, мира, справедливости;

- пропаганда превосходства одной организации, религии, группы, нации над другой;

- пропаганда «нелегитимности» действий противника и его «нечестивости».

Следует отметить, что зачастую в рамках этих приемов используются религиозные тексты, изначально не несущие в себе экстремистское содержание, однако их трактовка или компоновка в креолизованные тексты (мемы, карикатуры и пр.) способствует искаженному восприятию изначальных смысловых посылов. Указанный прием используется не только в русскоязычном сегменте Интернета, на его использование указывается в исследованиях ученых Массачусетского университета и Университета Джорджии [47].

Описанные выше механизмы и приемы являются действенными и наиболее популярными на данный период времени, однако при этом не носят исключительный характер. В связи с этим в мировой и российской практике обсуждаются возможности противодействия описанным приемам радикализации молодых поколений и искажения содержания их социализации. Так, в частности, такой возможностью является введение законодательных норм (например, ст. 282 УК РФ, ФЗ № 136 от 29 июня 2013 г. и др.) или жесткий административный контроль за интернет-контентом, в том числе формируемым частными лицами [48], посредством аналитики большого объема данных $[22,49,50]$.

В то же время, при анализе всех составляющих важно применять междисциплинарный подход для установления более подробного механизма действия экстремистских объединений. Как указывают C. Edwards и L. Gribbon [51], необходимо сосредоточить свои усилия на понимании не только содержательного контента, доступного в сети Интернет, но и на способах использования этого содержимого в процессе радикализации молодежи и ее вовлечения в экстремистские сообщества.

\section{Заключение}

В заключение отметим, что перечень приемов и механизмов, которые используются в Интернете для вовлечения молодежи в деятельности экстремистских сообществ, едва ли разумно ограничивать только теми позициями, которые нашли отражение в этой статье. Стремительное развитие Интернета приводит к тому, что в арсенале его возможностей регулярно появляются какие-то новшества, и очевидно, что каждое из них потенциально может использоваться не только в позитивных целях, но и в негативных. Кроме того, 
экстремистские сообщества действуют максимально гибко, подстраиваясь и под специфику сиюминутных настроений молодежи, и под необходимость избегать внимания правоохранительной системы. Поэтому очевидно, что перечень тех приемов и механизмов, которые они используют для работы с молодежью в Интернете, будет расширяться. В то же время, представленный в статье анализ показывает, что для нейтрализации указанных угроз в любом случае целесообразно, помимо административных методов контроля интернет-контента, формировать резистентность молодежи к интернет-воздействию со стороны таких экстремистских сообществ.

\section{Благодарности}

Исследование выполнено при финансовой поддержке РФФИ в рамках научно-исследовательского проекта «Интернет как инструмент формирования психологической готовности молодежи к экстремистскому поведению», проект № 16-29-09512.

\section{Acknowledgments}

This study received funding from the Russian Foundation for Basic Research (project no. 16-29-09512, "Internet as a tool for the formation of young people's psychological readiness to extremist behavior").

\section{Литература}

1. Федорова О. Н. Роль информационно-психологической безопасности граждан в России // Гуманитарные и социальные науки. 2012. № 2. С. 342-355.

2. Awan I. Cyber threats and cyber terrorism: The internet as a tool for extremism // Blakemore B. Policing Cyber Hate, Cyber Threats and Cyber Terrorism. Farnham: Ashgate Publishing Ltd, 2012. P. 21-38.

3. Greenberg K. J. Counter-Radicalization via the Internet // Annals of the American Academy of Political and Social Science. 2016. Vol. 668, № 1. P. 165-179. DOI: $10.1177 / 0002716216672635$

4. Southers E., Heinz J. Foreign Fighters: Terrorist Recruitment and Countering Violent Extremism (CVE) Programs in Minneapolis-St. Paul. Los Angeles: Create Center, University of Southern California, 2015. 46 p.

5. Vidino L., Hughes S. ISIS in America: From Retweets to Raqqa. George Washington University Program on Extremism. Washington, DC: George Washington University, 2015. 35 p.

6. Черных А. Мир современных медиа. М.: Издательский дом «Территория будущего», 2007. 312 с.

7. Чистяков А. В. Социализация личности в виртуальном пространстве: монография. Ростов-на-Дону: Изд-во Рост. ун-та, 2006. 182 с. 
8. Barber T. Participation, citizenship, and well-being: Engaging with young people, making a difference // Young. 2009. Vol. 17, Issue 1. P. 25-40. DOI: 10.1177/110330880801700103

9. Ødegård G. Political socialization and influence at the mercy of politicians: A study of a local participation project amongst young people in Norway // Young. 2007. Vol. 15, Issue 3. P. 273-297. DOI: $10.1177 / 110330880701500304$

10. Луков В. А. Теории молодежи: Междисциплинарный анализ: науч. монография. М.: Канон+, 2012. 389 с.

11. Baizerman M., Magnuson D. Do we still need youth as a social stage? // Young. 1996. Vol. 4, Issue 3. P. 48-60. DOI: $10.1177 / 110330889600400304$

12. Morimoto S. A., Friedland L. A. The Lifeworld of Youth in the Information Society // Youth \& Society. 2011.Vol.43, Issue 2.P.549-567.DOI:10.1177/0044118X10383655

13. Conway M. From "Cyberterrorism" to "Online Radicalism" // Eid M. Exchanging Terrorism Oxygen for Media Airwaves: The Age of Terroredia. Ottawa: IGI Global, 2014. P. 198-217. DOI: 10.4018/978-1-4666-5776-2.ch014

14. Винер Н. Кибернетика и общество. М.: Иностранная литература, 1958. 200 c. URL: https://www.gumer.info/bibliotek Buks/Science/viner/ (дата обращения 29.03.2018).

15. Тоффрлер Э. Шок будущего. М.: АСТ, 2002. 557 с.

16. Ефимова Т.В. Интернет как среда социализации современной личности // В мире научных открытий. 2011. № 5-4 (41). С. 195-209.

17. Минаков А. В. Некоторые психологические свойства и особенности Интернет как нового слоя реальности. URL: http://sbiblio.com/BIBLIO/archive/ minakov some psihological properties/ (дата обращения 29.03.2018).

18. Крылова И. В., Непомнящий А. В. К проблеме социализации личности в информационном обществе // Научные проблемы гуманитарных исследований. 2011. № 3. С.174-182.

19. Угольков Н. В. Влияние Интернета на социализацию старших школьников // ИСОМ. 2012. № 4. С. 173-174.

20. Morris M., Ogan C. The Internet as Mass Medium // Journal of ComputerMediated Communication. 1996. Vol. 1, Issue 4. P. 39-50. DOI: 10.1111/j.10836101.1996.tb00174.x

21. Bühl A. Die virtuelle Gesellschaft des 21. Jahrhunderts. Sozialer Wandel im digitalen Zeitalter. Wiesbaden: Westdeutscher Verlag, 2000. 541 p.

22. Conway M. Determining the Role of the Internet in Violent Extremism and Terrorism: Six Suggestions for Progressing Research // Studies in Conflict and Terrorism. 2017.Vol. 40, Issue 1. P. 77-98. DOI: 10.1080/1057610X.2016.1157408

23. Meleagrou-Hitchens A., Alexander A., Kaderbhai N. The impact of digital communications technology on radicalization and recruitment // International Affairs. 2017. Vol. 93, Issue 5. P. 1233-1249. DOI: 10.1093/ia/iix103 
24. Schils N., Verhage A. Understanding How and Why Young People Enter Radical or Violent Extremist Groups // International Journal of Conflict and Violence. 2017. Vol. 11. P. 1-17. DOI: $10.4119 /$ UNIBI/ijcv.473

25. Ермакова Е. С. Информационная война как атрибут информационного общества: активизация медиафункции насилия над сознанием // Современная наука: актуальные проблемы теории и практики. 2012. № 2. URL: http://www.vipstd.ru/nauteh/index.php/--gn12-02/403-а. (дата обращения 29.03.2018).

26. Карасик В. И. Языковой круг: личность, концепты, дискурс. М.: Гнозис, 2004. 390 c.

27. Дейк Т. А. ван. Вопросы прагматики текста // Новое в зарубежной лингвистике. 1978. № 8. С. 259-336.

28. Дейк Т. А. ван. Язык. Познание. Коммуникация: пер. с англ. / сост. В. В. Петрова. М.: Прогресс, 1989. 312 с.

29. Лосев А. Ф. Введение в общую теорию языковых моделей. М.: Наука, 1968. 296 c.

30. Блинова О. А. Экстремизм как результат обретения негативной персональной идентичности // Вестник Челябинского государственного университета. 2016. № 5 (387). С. 25-32.

31. Ворошилова М. Б. Когнитивный арсенал и коммуникативные стратегии современного националистического дискурса // Политическая лингвистика. 2014. № 3 (49). С. 242-245.

32. Шейгал Е. И. Семиотика политического дискурса. Волгоград: Перемена, 2000. 368 c.

33. Карапетян А. А., Тагильчева Ю. Р. Принцип интолерантности как психологическая основа экстремистского дискурса: коммуникативные тактики и приемы дискредитации «врага» // Политическая лингвистика. 2017. № 6 (66). С. 235-240.

34. Бабикова М. Р., Ворошилова М. Б. Контекстные прецедентные феномены как способ репрезентации националистических идей // Политическая лингвистика. 2017. № 6 (66). С. 58-63.

35. Карапетян А. А., Тагильчева Ю. Р. Игры с разумом, или Приемы и средства информационно-психологического воздействия в практике религиозно-политического экстремизма // Вестник Пятигорского государственного лингвистического университета. 2015. № 1. С. 270-272.

36. Маркин В. В., Роговая А. В. Противодействие распространению идеологии экстремизма и терроризма в молодежной среде. 2-я часть // Власть. 2012. № 12. С. 114-118.

37. Бабикова М. Р. Националистический дискурс: социолингвистический подход // Материалы VII Всероссийской научно-практической Ин- 
тернет-конференции «Язык и право: актуальные проблемы взаимодействия». 2017. URL: http://www.ling-expert.ru/conference/langlaw7/ babikova.html\#more-3329 (дата обращения 29.03.2018).

38. Johnson N. F., Zheng M., Vorobyeva Y., Gabriel A., Qi H., Velasquez N., Manrique P., Johnson D., Restrepo E., Song C., Wuchty S. New online ecology of adversarial aggregates: ISIS and beyond // Science. 2016. Vol. 352, Issue 6292. P. 1459-1463. DOI: $10.1126 /$ science.aaf0675

39. Бабикова М. Р., ТагильцеваЮ. Р. Экстремистский дискурс: основные критерии анализа материалов экстремистской направленности в Интернет // Политические институты и процессы. 2016. № 3. С. 66-69.

40. Бабикова М. Р. Славянские образы в современном националистическом дискурсе // Менталитет славян и интеграционные процессы: история, современность, перспективы: материалы X Международной научной конференции, Гомель, 25-26 мая 2017 г. / под общ. ред. В. В. Кириенко. Гомель: Изд-во ГГТУ им. П. О. Сухого, 2017. С. 297-299.

41. Ворошилова М. Б. Вербальное контекстуальное окружение нацистской символики в современном экстремистском дискурсе // Проблемы истории, филологии, культуры. 2016. № 3 (53). С. 150-157.

42. Мардиева Л. А. Социокультурная реальность и ее интерпритации в медиатекстах. Опыт интегративного исследования. Казань: Изд-во Казан. ун-та, 2016. 358 с.

43. Антонова Ю. А. Веснина Л. Е., Злоказов К. В., Тагильчева Ю. Р., Kарапетян А. А. Экстремистский текст и деструктивная личность: моногр. Екатеринбург: Изд-во Уральского гос. пед. ун-та, 2014. 272 с.

44. Тагильчева Ю. Р. Экстремистский дискурс: средства и приемы информационно-психологического воздействия // Ислам на Урале: история, современность, вызовы / Регион. Дух. Упр. мусульман Свердл. обл. в составе Центр. Дух. Упр. мусульман России, Урал. ассоц. «Центр этноконфес. исслед., профилактики экстремизма и противодействия идеологии терроризма» при поддержке Адм. Губернатора Свердл. обл.; [сост. и отв. ред. А. Н. Старостин]. Екатеринбург: Свердловская областная межнациональная библиотека, 2017. С. 31-39.

45. Ворошилова М. Б. Реконструкция культурных смыслов визуальных символов в современном националистическом дискурсе // Региональная картина мира в языковой концептуализации: динамика культурных смыслов. Сборник статей под ред. Л. А. Мардиевой, Т. Ю. Щуклиной. Казань: Изд-во Казанского (Приволжского) федерального университета, 2016. С. 22-25.

46. Ворошилова М. Б. Политический креолизованный текст: ключи к прочтению. Екатеринбург: Изд-во Уральского гос. пед. ун-та, 2013. 193 с. 
47. Arpinar I. B., Kursuncu U., Achilov D. Social Media Analytics to Identify and Counter Islamist Extremism: Systematic Detection, Evaluation, and Challenging of Extremist Narratives Online // 2016 International Conference on Collaboration Technologies and Systems (CTS). IEEE, 2016. P. 611-612. DOI: $10.1109 /$ CTS.2016.0113

48. Walker C. The War of Words with Terrorism: An Assessment of Three Approaches to Pursue and Prevent // Journal of Conflict and Security Law. 2017. Vol. 22, Issue 3. P. 523-551. DOI: $10.1093 / \mathrm{jcsl} / \mathrm{krx009}$

49. Fu T., Abbasi A., Chen H. A focused crawler for Dark Web forums // Journal of the American Society for Information Science and Technology. 2010. Vol. 61, Issue 6. P. 1213-1231. DOI: 10.1002/asi.21323

50. Scott J., Spaniel D. The Anatomy of Cyber-Jihad. Washington: CreateSpace Independent Publishing Platform, 2016.112 p.

51. Edwards C., Gribbon L. Pathways to Violent Extremism in the Digital Era//The RUSI Journal. 2013. Vol. 158, Issue 5. P. 40-47. DOI: 10.1080/03071847.2013.847714

\section{References}

1. Fedorova O. N. The role of information and psychological security of citizens in Russia. Gumanitarnye i sotsial'nye nauki - Humanities and Social Sciences, 2012, no. 2, pp. 342-355 (in Russian).

2. Awan I. Cyber threats and cyber terrorism: The internet as a tool for extremism. In: Blakemore B. Policing cyber hate, cyber threats and cyber terrorism. Farnham, Ashgate Publishing Ltd, 2012, pp. 21-38.

3. Greenberg K. J. Counter-radicalization via the Internet. Annals of the American Academy of Political and Social Science, 2016, V. 668, no. 1, pp. 165-179. DOI: $10.1177 / 0002716216672635$

4. Southers E., Heinz J. Foreign fighters: Terrorist recruitment and countering violent extremism (CVE) programs in Mminneapolis-St. Paul. Los Angeles, Create Center, University of Southern California, 2015. 46 p.

5. Vidino L., Hughes S. ISIS in America: From Retweets to Raqqa. George Washington University Program on Extremism. Washington, DC, George Washington University, 2015. 35 p.

6. Chernykh A. Mir sovremennykh media [The world of modern media]. Moscow, Territoriya budushchego Publ., 2007. 312 p.

7. Chistyakov A. V. Sotsializatsiya lichnosti v virtual'nom prostranstve [Socialization of personality in the virtual space]. Rostov-on-Don, Rostov State University Publ., 2006. 182 p.

8. Barber T. Participation, citizenship, and well-being: Engaging with young people, making a difference. Young, 2009, V. 17, Issue 1, pp. 25-40. DOI: $\underline{10.1177 / 110330880801700103}$ 
9. Ødegård G. Political socialization and influence at the mercy of politicians: A study of a local participation project amongst young people in Norway. Young, 2007, V. 15, Issue 3, pp. 273-297. DOI: 10.1177/110330880701500304

10. Lukov V. A. Teorii molodezhi: Mezhdistsiplinarnyi analiz [Theories of youth: Interdisciplinary analysis]. Moscow, Kanon+, 2012. 389 p.

11. Baizerman M., Magnuson D. Do we still need youth as a social stage? Young, 1996, V. 4, Issue 3, pp. 48-60. DOI: 10.1177/110330889600400304

12. Morimoto S. A., Friedland L. A. The lifeworld of youth in the information society. Youth \& Society, 2011,V.43, Issue 2, pp. 549-567.DOI:10.1177/0044118X10383655

13. Conway M. From "cyberterrorism"to"online radicalism". In: Eid M. Exchanging terrorism oxygen for media airwaves: The age of terroredia. Ottawa, IGI Global, 2014, pp. 198-217. DOI: 10.4018/978-1-4666-5776-2.ch014

14. Wiener N. Cybernetics and society. Moscow, Inostrannaya literatura Publ., 1958. 200 p. Available at: https://www.gumer.info/bibliotek Buks/Science/ viner/ (Accessed 29 March 2018).

15. Toffler A. Future shock. Moscow, AST Publ., 2002. 557 p. (in Russian).

16. Efimova T. V. Internet as an environment of socialization of modern personality. V mire nauchnykh otkrytii - In the World of Scientific Discoveries, 2011, no. 5-4 (41), pp. 195-209 (in Russian).

17. Minakov A. V. Some psychological characteristics and features of the Internet as a new layer of reality. Available at: http://sbiblio.com/BIBLIO/archive/ minakov some psihological properties/ (Accessed 29 March 2018).

18. Krylova I. V., Nepomnyashchii A. V. On the problem of socialization of personality in the information society. Nauchnye problemy gumanitarnykh issledovanii - Scientific Problems of Humanitarian Research, 2011, no. 3, pp. 174-182 (in Russian).

19. Ugol'kov N. V. The internet influence on socialization of senior school students. ISOM - Historical and Social-Educational Ideas, 2012, no. 4, pp. 173-174 (in Russian).

20. Morris M., Ogan C. The Internet as mass medium. Journal of ComputerMediated Communication, 1996, V. 1, Issue 4, pp. 39-50. DOI: 10.1111/j.10836101.1996.tb00174.x

21. Bühl A. Die virtuelle Gesellschaft des 21. Jahrhunderts. Sozialer Wandel im digitalen Zeitalter. Wiesbaden: Westdeutscher Verlag, 2000. 541 p.

22. Conway M. Determining the role of the Internet in violent extremism and terrorism: Six suggestions for progressing research. Studies in Conflict and Terrorism, 2017, V. 40, Issue 1, pp. 77-98. DOI: 10.1080/1057610X.2016.1157408

23. Meleagrou-Hitchens A., Alexander A., Kaderbhai N. The impact of digital communications technology on radicalization and recruitment. International Affairs, 2017, V. 93, Issue 5, pp. 1233-1249. DOI: 10.1093/ia/iix103 
24. Schils N., Verhage A. Understanding how and why young people enter radical or violent extremist groups. International Journal of Conflict and Violence, 2017, V. 11, pp. 1-17. DOI: $10.4119 /$ UNIBI/ijcv.473

25. Ermakova E. S. Information war as an attribute of the information society: Activation of the media function of violence over consciousness. Modern Science: Actual Problems of Theory and Practice, 2012, no. 2. Available at: http:// www.vipstd.ru/nauteh/index.php/--gn12-02/403-a. (Accessed 29 March 2018).

26. Karasik V. I. Yazykovoi krug: lichnost', kontsepty, diskurs [Language circle: Personality, concepts, and discourse]. Moscow, Gnozis Publ., 2004. 390 p.

27. van Dijk T. A. Issues of the pragmatics of text. Novoe v zarubezhnoi lingvistike - New in Foreign Linguistics, 1978, no. 8, pp. 259-336 (in Russian).

28. van Dijk T. A. Language. Knowledge. Communication. Moscow, Progress Publ. 1989. 312 p. (in Russian).

29. Losev A. F. Vvedenie vobshchuyu teoriyu yazykovykh modelei [Introduction to the general theory of language models]. Moscow, Nauka Publ., 1968. 296 p.

30. Blinova O. A. Extremism as a result of acquiring a negative personal identity. Vestnik Chelyabinskogo gosudarstvennogo universiteta-Bulletin of Chelyabinsk State University, 2016, no. 5 (387), pp. 25-32 (in Russian).

31. Voroshilova M. B. Cognitive arsenal and communicative strategies of modern nationalist discourse. Politicheskaya lingvistika - Political Linguistics, 2014, no. 3 (49), pp. 242-245 (in Russian).

32. Sheigal E. I. Semiotika politicheskogo diskursa [Semiotics of political discourse]. Volgograd, Peremena Publ., 2000. 368 p.

33. Karapetyan A. A., Tagil'tseva Yu. R. Principle of intolerance as a psychological basis of extremist discourse: Communicative tactics and techniques for discrediting the 'enemy'. Politicheskaya lingvistika - Political Linguistics, 2017, no. 6 (66), pp. 235-240 (in Russian).

34. Babikova M. R., Voroshilova M. B. Contextual precedent phenomena as a way of representation of nationalist ideas. Politicheskaya lingvistika - Political Linguistics, 2017, no. 6 (66), pp. 58-63 (in Russian).

35. Karapetyan A. A., Tagil'tseva Yu. R. Mind games, or the techniques of information and psychological influence in the practice of religious and political extremism. Vestnik Pyatigorskogo gosudarstvennogo lingvisticheskogo universiteta - Bulletin of Pyatigorsk State Linguistic University, 2015, no. 1, pp. 270-272 (in Russian).

36. Markin V. V., Rogovaya A. V. Countering the spread of the ideology of extremism and terrorism among young people: Part 2. Vlast' - Power, 2012, no. 12, pp. 114-118 (in Russian).

37. Babikova M. R. Natsionalisticheskii diskurs: sotsiolingvisticheskii podkhod [Nationalist discourse: A sociolinguistic approach]. Materialy VII Vseros- 
siiskoi nauchno-prakticheskoi Internet-konferentsii "Yazyk i pravo: aktual'nye problemy vzaimodeistviya" [Proc. the VII All-Russian Theoretical and Practical Internet Conference "Language and law: Actual problems of interaction"]. 2017, Available at: http://www.ling-expert.ru/conference/langlaw7/babikova. html\#more-3329 (Accessed 29 March 2018).

38. Johnson N. F., Zheng M., Vorobyeva Y., Gabriel A., Qi H., Velasquez N., Manrique P., Johnson D., Restrepo E., Song C., Wuchty S. New online ecology of adversarial aggregates: ISIS and beyond. Science, 2016, V. 352, Issue 6292, pp. 1459-1463. DOI: $10.1126 /$ science.aaf0675

39. Babikova M. R., Tagil'tseva Yu. R. Extremist discourse: Basic criteria for the analysis of extremist materials on the Internet. Politicheskie instituty i protsessy Political Institutions and Processes, 2016, no. 3, pp. 66-69 (in Russian).

40. Babikova M. R. Slavyanskie obrazy v sovremennom natsionalisticheskom diskurse [Slavic images in the modern nationalist discourse]. Mentalitet slavyan i integratsionnye protsessy: istoriya, sovremennost', perspektivy: materialy X Mezhdunarodnoi nauchnoi konferentsii [Proc. the X International Theoretical Conference"Slavic mentality and integration processes: History, modernity, and prospects]. Gomel, State Technical University of Gomel Publ., 25-26 May, 2017, pp. 297-299.

41. Voroshilova M. B. Verbal contextual environment of Nazi symbols in modern extremist discourse. Problemy istorii, filologii, kul'tury - Problems of History, Philology, and Culture, 2016, no. 3 (53), pp. 150-157 (in Russian).

42. Mardieva L. A. Sotsiokul'turnaya real'nost' i ee interpritatsii v mediatekstakh. Opyt integrativnogo issledovaniya [Socio-cultural reality and its interpretation in media texts: The experience of integrative research]. Kazan, Kazan University Publ., 2016. 358 p.

43. Antonova Yu. A. Vesnina L. E., Zlokazov K. V., Tagil'tseva Yu. R., Karapetyan A. A. Ekstremistskii tekst i destruktivnaya lichnost' [Extremist text and destructive personality]. Yekaterinburg, USPU Publ., 2014. 272 p.

44. Tagil'tseva Yu. R. Extremist discourse: Means and techniques of information and psychological impact. In: Starostin A. N. (ed.) Islam na Urale: istoriya, sovremennost', vyzovy [lslam in the Urals: History, the present, and challenges]. Ekaterinburg: Sverdlovskaya oblastnaya mezhnatsional'naya biblioteka Publ., 2017, pp. 31-39.

45. Voroshilova M. B. Reconstruction of cultural meanings of visual symbols in modern nationalist discourse. In: Mardievoi L. A., Shchuklinoi T. Yu. (eds.) Regional'naya kartina mira vyazykovoi kontseptualizatsii: dinamika kul'turnykh smyslov [Regional picture of the world in language conceptualization: Dynamics of cultural meanings]. Kazan, Kazan Federal University Publ., 2016, pp. 22-25. 
ЮРИДИЧЕСКАЯ ПСИХОЛОГИЯ

46. Voroshilova M. B. Politicheskii kreolizovannyi tekst: klyuchi kprochteniyu [Political creolized text: keys for reading]. Ekaterinburg, USPU Publ., 2013. 193 p.

47. Arpinar I. B., Kursuncu U., Achilov D. Social media analytics to identify and counter Islamist extremism: Systematic detection, evaluation, and challenging of extremist narratives online. 2016 International Conference on Collaboration Technologies and Systems (CTS). IEEE, 2016, pp. 611-612. DOI: 10.1109/CTS.2016.0113

48. Walker C. The war of words with terrorism: An assessment of three approaches to pursue and prevent. Journal of Conflict and Security Law, 2017, V. 22, Issue 3, pp. 523-551. DOI: 10.1093/jcsl/krx009

49. Fu T., Abbasi A., Chen H. A focused crawler for Dark Web forums. Journal of the American Society for Information Science and Technology, 2010, V. 61, Issue 6, pp. 1213-1231. DOI: 10.1002/asi.21323

50. Scott J., Spaniel D. The anatomy of cyber-jihad. Washington, CreateSpace Independent Publishing Platform, 2016. 112 p.

51. Edwards C., Gribbon L. Pathways to violent extremism in the digital era. The RUSI Journal, 2013, V. 158, Issue 5, pp. 40-47. DOI: 10.1080/03071847.2013.847714 